\title{
UTU: FINDING A BALANCE FOR THE LEGAL MĀORI DICTIONARY
}

Tai Ahu,* Rachael Hoare $* *$ and Māmari Stephens $* * *$

This article describes the authors' experience of attempting to confine the word utu to a list of distinct, Western legal glosses. The article highlights the complexity involved in drafting a comprehensive legal dictionary entry for utu that achieves an appropriate balance between the traditional customary meanings and Western legal meanings.

\section{INTRODUCTION: THE LEGAL MĀORI PROJECT}

Since the arrival of Europeans in Aotearoa, the Māori language has played an important role in communicating a wide range of Western legal concepts. Te reo Māori was used frequently by Māori themselves, often to voice their concerns about Crown acquisition of land. Colonial governments, institutions and Crown representatives also used Māori in official correspondence and other documentation dating from circa 1828. Despite the widespread historical use of Māori in various political and legal contexts, there has been little study of the Māori terms used in such discourse and the manner of their use.

The Legal Māori Project ("Project") began in early 2007 at the Faculty of Law at Victoria University of Wellington to explore the historical and contemporary use of Māori in Western legal discourse. This project aims to create a dictionary of legal Māori terms, submitted for publication in early 2012 . The dictionary is to be constructed by researching legal terms identified in our corpus of

* Tai Ahu (nō Waikato) is Assistant Lecturer in Law at Victoria University of Wellington and a research assistant for the Legal Māori Project.

** Rachael Hoare (Ngāti Pākehā) is a research assistant for the Legal Māori Project and an assistant Crown Counsel with the Crown Law Office.

*** Māmari Stephens (Te Rarawa) is a Lecturer in law at the Faculty of Law at Victoria University of Wellington in New Zealand and co-leader of The Legal Māori Project. The Project is co-led by Dr Mary Boyce from the University of Hawai'i at Manoa. 
Māori language texts ("corpus") that consists of eight million words of running text; to our knowledge this is the largest constructed corpus of Māori language texts yet designed. ${ }^{1}$

The creation of a dictionary of legal terms in Māori poses a number of important questions. The Project researchers have had to grapple with the relationship between customary legal meanings and Western legal concepts. For reasons of expense and the availability of excellent English language legal dictionaries, our dictionary will not include full definitions of the Western legal concepts underpinning or described by the terms. Instead it will provide useful English glosses for each term and Māori language usage examples derived from corpus texts. In this way the dictionary is expected to be a useful tool for intermediate-level language learners, as well as for Māori speaking practitioners and students of law. ${ }^{2}$

Just as the dictionary will not define Western legal ideas, it will not comprehensively or exhaustively define the customary legal ideas within it. Nevertheless there are many customary legal ideas that will be expressed in the dictionary that require particular attention in the formatting of the dictionary to ensure that readers are able to use the dictionary with confidence. In fact the Project has identified that customary legal concepts figure very prominently in Westernised legal Māori terminology. For example, the most frequent content word ${ }^{3}$ in the corpus is "whenua", which means "land" or "placenta", and occurs 79,235 times. "Tikanga", meaning "custom", "convention", or "lore", is the eighth most frequent content word, occurring 33,164 times. "Mana", another customary word which means "authority", "prestige", or "influence", occurs 20,163 times.

When customary words are used to describe Western legal concepts, these terms retain elements of their customary meaning. The dual nature of these terms and the desire to capture the richness of Māori customary terminology in Western legal discourse pose some interesting problems for lexicographers seeking to identify and describe legal Māori language in constructing a specialised, bilingual dictionary. One assumption of this article is that it is important that a dictionary user does not overlook the importance of the underlying customary concept to gain an understanding of the appropriate legal use of that term. However, there is also the risk that when drafting dictionary entries, overriding deference to customary concepts may compromise the usefulness of a specific legal gloss.

The term utu provides a useful illustration of how difficult this balance can be to achieve. The value of utu as a case study comes from its significance as a Māori customary concept, its high

1 For the purposes of the Project a "legal Māori text" which qualifies for inclusion in the corpus is a text that was printed in Māori, between 1828 and 2009, to be read or distributed to three or more Māori speakers, and for the communicative function of explaining, clarifying, challenging or using Western legal concepts.

2 A description of the Project and its outputs can be found at <www.victoria.ac.nz/law $>$.

3 A content word is a noun, verb or adjective that has a clear lexical meaning on its own, as opposed to a function word which serves a grammatical purpose. 
frequency (it occurs 16,552 times in the corpus) and its polysemic nature; it has several individually distinct but semantically related senses.

This article describes our experience of attempting to confine utu to a list of distinct, Western legal glosses, highlighting the complexity involved in drafting a comprehensive legal dictionary entry for utu that achieves an appropriate balance between traditional customary meanings. What follows in Part II is an overview of the customary meaning of utu. Part III explores the typical representation of utu in non-specialised dictionaries. Part IV describes the framework and mechanisms employed by the Project for identifying legal Māori terms which qualify for inclusion in the final dictionary and their discrete legal senses, before discussing the application of these principles to the term utu as it appears in the corpus. Part V considers the tensions that arise between the resulting list of Western legal glosses for utu and its customary understanding. Finally, Part VI argues that, in order to adequately provide a conceptual understanding of a term such as utu, a traditionally formatted dictionary entry must be amended to include important information about the term in its customary context. As will be shown, this is particularly important where underlying customary meanings conflict with Western legal senses.

\section{UTU AS A CUSTOMARY CONCEPT}

Since their arrival in Aotearoa, Māori have developed complex relationships with the natural environment and the spiritual world. In a Māori worldview, these relationships can be influenced, affected and prescribed by human actions. At its most general level of understanding, utu is a concept that describes the process of restoring these physical and spiritual relationships to an equal or harmonious state. ${ }^{4}$

The process of restoring balance can be very complex and therefore the term utu communicates a number of different, albeit semantically related, senses. In one sense, utu refers to providing compensation or redress. Raymond Firth, one of New Zealand's earliest anthropologists, wrote a useful description of utu in 1929: ${ }^{5}$

The general principle of Maori exchange was that for every gift another of at least equal value should be returned ... The word utu is often translated as meaning "payment", but its significance is broader than that. The root idea is that of "compensation" in the wide sense, of obtaining an equivalent. The concept of $u t u$ is not restricted merely to economic affairs, but is found in varying social context as one of the fundamental drives to action.

4 John Patterson Exploring Māori Values (Dunmore Press, Palmerston North, 1992) at 117.

5 Raymond Firth The Economics of the New Zealand Māori (Government Printer, Wellington, 1959) at 412 [emphasis added]. 
Utu is also a mechanism that enables one to maintain and increase personal or tribal mana. ${ }^{6}$ Where the mana of a chief is threatened, the chief must take steps to defend against the threat. Similarly, where an opportunity arises for the chief to increase the mana of his tribe, he is obliged to do so. ${ }^{7}$ In such instances "utu" provided the means of protecting mana. ${ }^{8}$ In terms of Māori custom, "utu" defines the process of compensation for breaches of tikanga Māori. According to tikanga Māori, disputes that arise from a breach of tikanga Māori require some form of utu to be paid to a wronged party. ${ }^{9}$ The utu itself can take many forms depending on the circumstances; however, "utu" has a compensatory role in restoring a breach of tikanga. Professor Hirini Moko Mead describes "utu" as part of a three-stage process of take, utu and ea, which aims to restore the relationship between a wronged party and an offender. ${ }^{10}$ Mead states that a breach of tikanga gives rise to a take, an issue or cause. ${ }^{11}$ This take requires an appropriate cultural response to compensate the wronged party and to achieve a state of ea, or harmony. ${ }^{12}$ An example can be found in the papers of Sir George Grey, which notes death as the appropriate penalty where a common person insults a high ranking chief: ${ }^{13}$

Tenei ano tetehi tikanga nui a te tangata Maori he whakataurekareka he kanga he tangata te $u t u$. Tetahi

hei patunga mo te ngakau mamae, he haka ara i mua i te ritenga Maori.

This translates as: ${ }^{14}$

6 Patterson, above $\mathrm{n}$ 4, at 117.

7 Ibid.

8 Anne Salmond Hui: A Study of Māori Ceremonial Gatherings (Reed Books, Auckland, 2002) at 13.

9 Hirini Moko Mead Tikanga Māori: Living by Māori Values (Huia Publishers, Wellington, 2003) at 27.

10 Ibid.

11 Ibid.

12 Mead (ibid) states that:

If an action is considered to be incorrect this gives ground for alleging a breach of tikanga. The breach becomes the take [issue or justification], which requires a resolution of some sort. A breach, however, involves parties who are aligned with the wrongdoer and with the wronged group. Both parties have to agree that there is a take before a resolution can be contemplated. Once a take is agreed upon there is often an appropriate utu (recompense), or some equivalent gesture may be given to the wronged party. The reason for doing so is to reach a resolution satisfying all parties so that the matter is resolved. This is the desired outcome, the state of ea.

13 George Grey GNZ MMSS 28 (1857) cited in R Benton, A Frame and P Meredith (eds) Te Mātāpunenga, A Compendium of References to the Concepts and Institutions of Māori Customary Law (Te Mātāhauariki Research Institute, Hamilton, 2007) at 432 (emphasis added).

14 The translation was done by Te Mātāhauariki Research Institute. See R Benton, A Frame and P Meredith, ibid [emphasis added]. 
Another significant practice of the Maori is to belittle by insult where only the person will suffice as payment. Firstly as payment for the stricken heart - haka is performed prior to the arrangements being set.

However, utu can also involve a positive response to a friendly or gracious act made towards a party. Sometimes these acts are remembered for generations and are returned in kind several years later. Anne Salmond, a New Zealand historian and anthropologist, recounted the story of the Waikato chief Te Rauparaha who was expelled from Kāwhia by his kinsman Pōtatau. ${ }^{15}$ As Te Rauparaha made his way southwards, he surrounded Pōtatau's camp, ready to exact utu for his expulsion from Kāwhia. As his men moved in, Pōtatau shouted "E Raha, he aha tō kōhā māku?" ("Raha, what is your gift to me?") ${ }^{16}$ The use of Te Rauparaha's nickname reminded Te Rauparaha that they were kinsmen, and he did not attack. ${ }^{17}$ Years later, when a descendant of Te Rauparaha contested the Western Māori seat in Parliament, he called on the support of Waikato voters. He said to the Waikato elders: "I heard a voice crying in the night E Raha, he aha tō kōhā māku?" Waikato instantly understood what was meant and that Te Rauparaha's act had not been repaid. Waikato supported the candidate, who later narrowly won the seat. ${ }^{18}$ In this instance, utu created a positive relationship between two iwi that lasted decades.

The underlying concept of restoring a balance sometimes provides a suitable description of analogous Western legal concepts. The papers of Sir George Grey contain an account of Te Rangikaheke, a prominent scholar from Te Arawa. ${ }^{19}$ Te Rangikaheke explains the protocol relating to moko, the Māori art of tattooing. Here, the idea of "utu" as "payment for services" is demonstrated: ${ }^{20}$

Ko nga $u t u$ mo nga moko. Te ritenga o nga $u t u$ ki te mea ka hiahia te tangata kia taia ona moko ona rape ranei, ka ata whakaritea e ia etahi utu mo te tohunga kia takoto, rite rawa. Katahi ka haere ki te tiki atu i te tohunga kia haere mai kia tata i a ia, ka oti te ta. Ka hoatu nga taonga hei utu mo te mahi o taua tohunga nei. He nui ano nga $u t u . .$.

This translates as: ${ }^{21}$

15 Salmond, above $\mathrm{n} 8$, at 20.

16 Ibid.

17 Ibid.

18 Ibid, at 21; James Cowan Tales of the Mãori Bush (AH and AW Reed, Dunedin, 1934) at 119-124.

19 Jenifer Curnow "Te Rangikaheke Wiremu Maihi - Biography" (2010) Dictionary of New Zealand Biography, Te Ara - the Encylopedia of New Zealand <www.teara.govt.nz>.

20 George Gray GNZ MMSS 89 [emphasis added].

21 The translation was done by Te Mātāhauariki Research Institute. See R Benton, A Frame and P Meredith, above $\mathrm{n} \mathrm{13}$, at 429-430 [emphasis added]. 
The payment for the tattoo: The arrangement of payment for persons who desire to be tattooed with a moko or a rape, will be carefully arranged as payment to be deferred to the priest. Then he proceeds to fetch the priest to come within close proximity to complete the tattooing. The treasures are given as payment for the priest. The payment is sizeable...

In certain situations, the idea of restoring a balance requires an act of vengeance or punishment. Utu in this context originated from warfare between the gods before mankind came into existence. Sir George Grey collected a written description of the revenge sought by Tümatauenga, the God of War, who sought to punish his brothers for their failure to support him in the feud against Tāwhirimatea, the God of the Wind. The following account demonstrates the customary idea of retribution or punishment: ${ }^{22}$

Na reira i kainga katoatia ai e Tumatauenga ona tuakana, a pau ake te kai e ia hei utu mo ra ratau tukunga i a ia ki te whawhai ki a Tawhiri raua ko Rangi, a mate katoa, ko ia anake te tangata i toa ki te whawhai

Translated: 23

Thus Tumatauenga devoured all his brothers, and consumed the whole of them in revenge for their having deserted him and left him to fight alone against Tawhirimatea and Rangi.

The idea of revenge or punishment conveyed by the term utu is also useful in describing Western forms of legal punishment. However, there are important differences between punishment and utu. John Patterson cautions against overlooking the difference between utu and Western legal punishment: ${ }^{24}$

Apart from the law of tapu, which can operate without the need of human intervention, [Māori] parallels to a European system of legal punishment are found in the practice of utu ... But the parallels are approximate only. Although both punishment and utu involve a deliberate response to an offence or injury and aim to achieve retribution or repayment, they differ in important respects. Ethically speaking, punishment can be foregone, but utu cannot; punishment should be unpleasant enough to deter, but utu may be entirely friendly and welcome; punishment should be confined to offenders who have been proven guilty of intentional offences, but utu may be extracted from individuals who have done no wrong. The aims of punishment are complex and contentious, but the aim of utu can be seen as more straightforward - utu is essentially a mechanism for restoring lost mana. If [Pākehā] are to understand Māori concepts and practices they must forget much of what they take for granted about punishment.

22 George Grey Nga Mahi a nga Tupuna (1854) cited in R Benton, A Frame and P Meredith, above n 13, at 432-433 [emphasis added].

23 This translation of George Grey's original text was done by Henry Williams. Ibid [emphasis added].

24 Patterson, above $\mathrm{n} 4$, at $134-135$. 


\section{UTU IN NON-SPECIALISED DICTIONARIES}

When considering the kind of customary information to accompany a dictionary of legal senses, it is useful to consider how the different customary senses of utu have been represented and classified in other, non-specialised dictionaries. Typically, dictionaries define utu by providing a concise set of English glosses or definitions. Sometimes these entries contain usage examples, but this is not always the case.

The following definition of the primary sense of utu appears in WH Williams' Dictionary of the Māori Language: ${ }^{25}$

Utu (i). 1. n. Return for anything; satisfaction, ransom, reward, price, reply. Ka tae te tangata ra ki tana taurekareka, ka hoatu hei utu mo te ruahine ra (N.41). No konei i maingatia ai e Manaia taua iwi nei, kia kahakore ai ratou ki te rapu utu ma ratou (N. 100). Kia whawhaitia he utu mo ta Raumati kino ki a Te Arawa i tahuna (N.70).

2. v.t. Make response, whether by way of payment, blow, or answer, etc. Katahi au ka utu, "Ko au, ko Rangimatinitini i runga" (M. 411). Kihai ano i utua (N. 172).

In the dictionary article above, a fairly traditional dictionary format is used. ${ }^{26} \mathrm{~A}$ brief explanation of the term is given in English, along with other related English glosses. This sense of utu is given two primary sets of meaning, each numbered and predicated on the grammatical function of the term first as a verb and then as a noun. For each set two or three usage examples in Māori are provided, and references are given for those usages.

The first set above refers to the use of utu as a noun; and identifies the notion of reciprocity the restoration of a situation of imbalance to a state of balance. In terms of the development of distinct Polynesian languages in the Pacific, this set of meanings derives from the Proto-Polynesian stage, approximately 1,200 years ago. ${ }^{27}$ The second set of meanings above refers to the use of utu as a verb denoting the act of making a response to some pre-existing state or circumstance. This second set of meanings contains the customary idea of "revenge" which derives from the Proto-Nuclear Polynesian stage. ${ }^{28}$ The revenge semantic is prevalent in other Pacific Island languages, including Hawaiian, Tuamotuan, Rarotongan and Tahitian. ${ }^{29}$ One benefit provided by these sets of meanings

25 HW Williams Dictionary of the Māori Language (Government Printer, Wellington, 1971) at 471.

26 These senses do not include the homonyms of utu which are not semantically related to the senses listed here. The different senses have been translated by Tai Ahu.

27 Tui Adams and others "Te Matapunenga: A Compendium of References to Māori Customary Law" (2003) Te Mātāhauariki Research Institute, Occasional Papers Number 8 <lianz.waikato.ac.nz〉.

28 R Benton, A Frame and P Meredith, above n 13, at 429

29 Ibid. 
is that it provides a useful starting point for a very flexible understanding of "utu"; either something done "in return for anything" or to "make a response".

In the monolingual dictionary He Pātaka Kupu, brief definitions are employed, rather than glosses (as translated below). One very interesting feature of the entry as partially set out below is the atua category. This category is a unique feature of He Pātaka Kupu which provides that each headword is assigned to the sphere of a relevant deity that reflects the focus of the word, thereby, according to Te Taura Whiri i te Reo Māori, reflecting a Māori worldview in the dictionary format that pays due respect to the sanctity of words as derived from the gods. ${ }^{30}$ As shown below the name of the relevant atua is located in square brackets and precedes the description of each sense.

In addition to the features just mentioned, the senses of utu are classified by reference to three primary senses, rather than by different grammatical functions, as used in Williams: ${ }^{31}$

Utu 1. [Tūmatauenga] ing. He mahi ka mahia, he taonga he aha atu rānei ka tukua, e ea ai tētahi āhuatanga kino pērā i te patunga o te tangata kia mate...

[Noun. Where something is done, or where something of value is given, in satisfaction of some evil situation akin to the beating of a person to death...]

2. [Tāne] Te rahi o te moni ka pau ki te hoko, ki te hanga rānei i tētahi mea...

[The sum of money used in order to purchase or create something...]

3. - $a-n g a$ [Tūmatauenga] mahw, ing, āhua. Ka mahi i tētahi mahi, ka tuku rānei i tētahi taonga, aha atu, e ea ai tētahi mahi pai; ka hoatu moni hei hoko mai i tētahi mea, hei whakakore rānei i te noho nama mō tētahi mea...

[Intransitive verb, noun, adjective. Where something is done, or where something of value is given, in satisfaction of a valuable service; money is given to purchase a thing, in order to dissolve an existing debt...]

This semantic order, focusing on primary senses is a common way of organising dictionary articles: ${ }^{32}$

A word's core meaning (sometimes referred to its "psychologically salient" meaning) is the one that feels, intuitively, to be central to any understanding of how the word works and how its other meanings have developed. In this ordering system, the core meaning is followed by those meanings that are

30 Te Taura Whiri i te Reo Māori He Pātaka Kupu: te kai a te rangatira (Penguin Group (NZ), North Shore, 2008) at ix.

31 Ibid, at 1039-1040. The different senses have been translated by Māmari Stephens.

32 BTS Atkins and M Rundell The Oxford Guide to Practical Lexicography (Oxford University Press, New York, 2008) at 251. 
semantically closest, with the more marginal uses appearing later ... [this method] is felt to give the user the most satisfying account of meaning.

The dictionary entry for utu in He Pātaka Kupu is useful because it provides a description of the types of circumstances where a response is customarily appropriate: in evil situations like the beating of a person to death, or in recognition of a valuable service. The Williams dictionary only identifies the fact that "utu" involves making some kind of response. He Pātaka Kupu also provides usage examples after each sense, allowing the user to get some understanding of utu in terms of sentence construction.

He Pātaka Kupu and Williams have provided the Project with food for thought in determining how best to craft the entry for utu, and in particular, how best to incorporate core customary meanings for our terms. We considered that ideally, information about the customary meaning of utu in a bilingual legal dictionary would need to precede Western legal ideas that it subsequently communicates. Placing customary meanings first, would allow the customary meaning of utu to give coherence to its later Western legal senses. The usefulness of the customary information would depend on providing a sufficiently general description of utu, while also providing some indication of the types of circumstances where utu was considered appropriate.

\section{FINDING THE SENSES OF UTU}

Before considering the specific issues that arose when creating a dictionary entry for utu, it is worthwhile to briefly describe the framework and mechanisms the Project employs for determining firstly which terms, and secondly which discrete legal meaning of terms, qualify for inclusion in the final dictionary.

\section{A Legal Māori Terms and their Legal Senses}

For the purposes of the Project, legal Māori terms have at least one meaning that is closely related to a Western legal concept. In Māori, as in English, many words can be used in a general context as well as in a legal context. Not all words and phrases used in a legal context comprise legal terminology. Some such words and phrases might be considered legal language in so far as the words include or impart legal connotations, because such words are likely to appear in legal contexts, but will not in themselves be legal terms. The completed Legal Māori Dictionary will include mainly legal Māori terms in it, but some words and phrases will be more accurately considered to be legal language. Researchers are encouraged to ask the following questions in order to determine whether the word or phrase they are examining constitutes legal language or more technical legal terminology.

In determining if a word or phrase has a connection to a Western legal concept, we asked whether it fulfilled one or more of the following requirements:

- It refers to a threshold or a legal test (for example, intention or reasonable doubt) to be met. 
- It is a label for a concept that is central to the practice or embodiment of Western law (for example, contract, title, guilt).

- It is a label for a thing that only exists because of the operation of a law (civil union, adoption).

- It is an idea adequately expressed by one or more of the above.

As another useful consideration, we emphasise that a legal term, for the purpose of this Project, is not:

- A descriptive phrase or sentence that might describe a legal test, concept, or entity but is not a fixed label for such things;

- A word that is merely defined in legislation and does not fit any of the three criteria mentioned above.

Many of the legal Māori terms have more than one discrete legal sense that could be described or glossed by any number of English language equivalents. The potential for confusion is large. When reducing the list of available Western legal glosses to a manageable list of discrete legal senses for the purposes of producing a dictionary entry, research assistants are therefore encouraged to consider whether the potential English glosses for the entry are truly sufficiently distinct to warrant the description of separate legal senses for the Māori term. A decision to merge glosses must always be subject to a careful assessment of the extent to which two given meanings overlap. In some cases, a valid legal distinction between ostensibly similar words is present and needs to be preserved. In some cases whether a term is used as a verb or a noun may dictate a slightly different sense. Whether that sense difference ought to be preserved in the entry is subject to debate.

It is also possible that where research assistants identify the English glosses for the Māori term, they are allowing English meanings to dictate the content of the dictionary, rather than allowing the Māori term to determine the content. As will be discussed in the next section we had to find another way, in formulating dictionary entries, that would address this risk.

\section{B Application to Utu}

The term utu is used in many different ways in the corpus texts. Sometimes it is used with specific legal meaning, either alone, or in combination with other words in a phrase. Sometimes the word utu can be used less as a fixed legal term, but more as a part of legal language with legal connotations. On other occasions in the texts of the corpus, it is used with primarily customary legal meanings. On other numerous occasions, utu is not used with legal or customary legal meaning at all, but with more general or colloquial meaning. The challenge for the research team was to fashion a dictionary entry that could do justice to the many layers of legal meaning of the word utu. The following table illustrates the distinct senses initially identified by the research team and the provisional frequency with which those senses were identified in the corpus of texts. 


\begin{tabular}{|c|c|}
\hline pay v. & 1462 \\
\hline payment, consideration $\mathrm{n}$. & 1580 \\
\hline cost, price $n$. & 809 \\
\hline bid, offer (an auction) & 1 \\
\hline value $\mathrm{v}$. & 200 \\
\hline charge $n$. & 116 \\
\hline compensation, recompense n. & 98 \\
\hline reimburse & 18 \\
\hline wages, salary n. & 64 \\
\hline remuneration (for services) $n$. & 7 \\
\hline award n. & 6 \\
\hline award (by a court) v. & 4 \\
\hline reward n. & 1 \\
\hline proceeds $n$. & 4 \\
\hline fee $n$. & 3 \\
\hline settle, discharge (a debt) v. & 43 \\
\hline purchase, buy v. & 32 \\
\hline sale $n$. & 9 \\
\hline sentence, punishment $\mathrm{n}$. & 29 \\
\hline debt, financial or monetary obligation $n$. & 28 \\
\hline confiscate $\mathrm{v}$. & 1 \\
\hline punish (an offender) v. & 14 \\
\hline settlement $\mathrm{n}$. & 5 \\
\hline grant $\mathrm{v}$. & 4 \\
\hline vest, revest v. & 3 \\
\hline revenge & 4 \\
\hline
\end{tabular}


As can be seen in this table, some of the distinctions between English glosses are fine, and the verb forms are treated as distinct from the noun forms. It is not clear that such distinction should always be preserved in the final dictionary entry. In some cases the English glosses chosen refer to legal concepts alike enough that the glosses can be merged without doing violence to the meaning or the utility of the entry. For example, "grant", "award" and "vest" are not sufficiently different to warrant separate entries, especially given that it is often not possible to glean enough from the Māori context to know for sure whether any particular variation was intended.

On the other hand, the glosses of "price", "payment", "consideration" and "cost" convey overlapping meanings to a large degree and the relationship between them is complex. However, it was decided that these are subtle differences in legal connotation conveyed by each word which meant that merging them would be inappropriate. Another example is the word settle, which can convey distinct Western legal ideas: the discharge of a debt or monetary obligation the resolution of a legal dispute between the parties by agreement without a formal hearing; convey or vest property. This example demonstrates that research assistants should not be too quick to conclude that English glosses are coextensive.

After identifying an original list of 26 senses, the research team has identified 11 different primary senses that deserve individual attention in the dictionary. Senses that appeared fewer than three times were excluded, and in most cases no distinction between the verb or noun form has been retained. Within each of the final senses, other minor senses have also been identified. The final list is set out as follows:

- $\quad$ pay (including purchase; repay; repayment)

- price (including consideration; cost)

- $\quad$ costs (including expenses; fees)

- value

- charge

- compensate (including compensation)

- $\quad$ remunerate (including wages, salary, allowances)

- $\quad$ settle (including discharging a debt, settlement)

- $\quad$ punish (including punishment, sentence, revenge)

- debt

- award.

In the process of identifying and isolating individual senses, the Project team became concerned that the Māori identity at the heart of the term utu was being compromised. Part V addresses this issue and the partial solution the Project team has developed to address this concern. 


\section{CONFLICTS BETWEEN LEGAL AND CUSTOMARY MEANINGS}

The specific legal glosses identified in the course of drafting the dictionary entry do not always reflect the nuances of the underlying Māori customary meaning of utu. However, the standard dictionary entry format encourages the presentation of such glosses as an apparently comprehensive list of senses. This format may lead a reader to an incorrect understanding of the customary meanings of the term utu. As one example, most of the senses identified in the original table and in the final list above relate to the economic aspects of utu. This focus occurs in part because that is how the term was primarily used within the corpus texts, and reflected the primary concerns of the Western legal system at the time. However the Project team is very aware that other aspects of utu, focusing on social or political obligation, ought not be forgotten or neglected in the final dictionary entry. But acknowledging those aspects of utu needs to be accomplished in a way that does not subvert the data on the term.

We have also identified three other specific points of departure between the legal and customary meanings of utu that ought to be taken into account in the final format of the dictionary. These are discussed in turn below.

\section{A Maintaining Relationships}

Whereas utu as a customary concept is principally concerned with the maintenance of relationships, utu in the Western sense of compensation or damages is more about ending them.

In Western legal systems compensation and most forms of damages focus on restoring an injured party to the position that he or she was in but for the loss or injury suffered. In the field of contract law, since at least 1848 courts have adopted the principle of restitution in integrum as the method of evaluating and quantifying damages as a remedy for breaches of contract. ${ }^{33}$ This principle requires that "[i]f the plaintiff has suffered damage ... he or she must, so far as money can do it, be restored to the position that he or she would have been in had the breach of contract not occurred". ${ }^{34}$ Similarly, compensatory damages are the primary remedy sought by victims of tortious wrongs. ${ }^{35}$ The guiding principle for quantifying compensatory damages is "that the court would award as compensatory damages the sum of money required to put the plaintiff into the position that he or she would have been in if the wrong had not occurred". ${ }^{36}$ As these damages are "assessed only

33 John Burrows, Jeremy Finn and Stephen Todd Law of Contract in New Zealand (3rd ed, LexisNexis, Wellington, 2007) at [27.2.1].

34 Ibid.

35 Stephen Todd (ed) The Law of Torts in New Zealand (5th ed, Brookers, Wellington, 2009) at [25.1].

36 Ibid, at [25.2.01], citing Livingstone v Raywards Coal Co (1880) 5 App Cas 25 (HL) at 39; Czarnikow v Koufos (The Heron II) [1969] 1 AC 350 (HL) at 420; Attorney-General v Geothermal Produce New Zealand Ltd [1987] 2 NZLR 348 (CA) at 359 and 370. 
once in respect of each cause of action and awarded in a single lump sum", plaintiffs "must sue for all losses, past and future, arising from that cause of action". ${ }^{37}$

Only in exceptional situations will the courts depart from the general principle that damages are awarded to make good any loss suffered by the plaintiff at the hands of the defendant, such as by awarding exemplary or punitive damages, by which a "court may seek to express its particular disapproval of the defendant's conduct" in a manner that is "unrelated to loss suffered by the plaintiff". ${ }^{38}$

This is not necessarily consistent with the customary philosophy of restoring a balance. As Patterson states: ${ }^{39}$

[I]t is common when giving or taking utu to do or take rather more than was done to or taken from you. It is not a matter of taking precisely an 'eye for an eye'. The ideal response to the killing of an important kinsman is the killing of a more important member of the other group; the proper response to lavish hospitality is rather more lavish hospitality. Now if utu were simply a matter of restoring balance this would not be so. Strict balance involves exactly equal and opposite forces, not rather more than equal ones. But if we see utu as involving the pursuit of mana this makes good sense. It is better never to have had mana than to have had it but then lost it. A loss of mana in itself involves a further loss of mana, and so in seeking utu one needs more than an 'eye for an eye'. So when we think of utu in terms of balance, we should think of a dynamic balance rather than a static balance.

\section{B Duty to Seek Utu}

A second difference exists between the customary meaning of utu and a number of English glosses, in particular "compensation", "recompense" and "remuneration". To seek utu is a legal duty according to Māori customary law. As Patterson states: ${ }^{40}$

With utu ... there is always and necessarily an obligation. It is not up to the individual, or indeed to the chief of a tribe, to decide whether to take utu. When and where and how to take it, yes, but not whether to do so ... Johansen quotes the account of a prisoner of war, captured by Te Rauparaha. He begged for his life, and was told that if it had been just a personal insult he would have been spared, but that as there had been an insult to the tribe, to Ngāti Toa, there was nothing that Te Rauparaha could do about it. Utu, as Johansen puts it, is a necessity, a downright duty ... And Gudgeon tells us that forbearance is a weakness of character, not a virtue: 'in no possible way can mana be more easily lost'.

37 Stephen Todd (ed), ibid, at [25.2.02].

38 Ibid, at [25.3].

39 Patterson, above $\mathrm{n} 4$, at 122.

40 Ibid. 
This idea can be contrasted with the position in Western legal systems that while a complainant may have a right to legal redress, he or she has discretion as to whether or not to enforce that entitlement. The contrast is especially apparent in criminal cases, where the direct relationship between defendant and victim is further sidelined by the conception of criminal activity as a harm against the state rather than against individual victims, and the consequent acceptance by state representatives of responsibility for criminal prosecutions. ${ }^{41}$

Even in a criminal context, Western legal systems recognise and defer to the role of police prosecutorial discretion in the criminal justice system. For example in Thompson $v$ AttorneyGeneral, ${ }^{42}$ the High Court refused to judicially review a police diversion decision on the basis that it involved "an intimate expression of the prosecutorial discretion", and that, "throughout the common law world, there [was] general acceptance that the Courts should not be involved in the exercise of the prosecutorial discretion". 43

This idea is further complicated by Western notions of statutory limitation periods or laches (whereby the opportunity to enforce a legal entitlement expires if not pursued within a certain time), which sit uneasily alongside the fact that in Māori society an imbalance could be remembered for years, or even decades, before taking an appropriate opportunity to extract utu.

\section{Nature of Punishment}

Finally, the gloss "punishment" reflects a narrower range of responses to conduct than those covered by the customary meaning of utu. Punishment occurs in Western legal systems where criminal justice procedures have been successfully invoked in response to some clear breach of the criminal law. By contrast, utu often operates as a mechanism to treat a perpetrator outside of what Māori customary law would consider a "hara" ["a breach of tikanga Māori"]. ${ }^{44}$ Patterson states that: ${ }^{45}$

41 Peter Sankoff "Constituents in the trial process: the evolution of the common law criminal trial in New Zealand" in Julia Tolmie and Warren Brookbanks (eds) Criminal Justice in New Zealand (LexisNexis, Wellington, 2007) at [8.1]. This element of the criminal trial is described as one of the "three pillars of the common law trial [that] have dominated the criminal justice framework for centuries."

42 Thompson v Attorney-General [2000] NZAR 583 (HC).

43 Ibid, at [24] citing $R v$ Commissioner of Police of the Metropolis, ex parte Blackburn [1968] 1 All ER 763 (CA); Barton v F (1980) 147 CLR 75 (HCA). See also Beneficial Owners of Whangaruru Whakaturia No 4 $v$ Warin [2009] NZCA 60, [2009] NZAR 523 (CA) at [28] where the fact that the relief sought in the proceedings would impinge on prosecutorial discretion was one of two factors to convince the Court of Appeal that the proceedings were significant enough to warrant the Attorney-General's involvement in the capacity of intervener rather than amicus curiae.

44 Patterson, above n 4, at 129.

45 Ibid. 
... many of the actions that result in a need for utu are not breaches of prohibitions belonging to a code of law. Some of course are, but traditional Maori law does not regard as offences many of the sorts of action that call for utu ... in the sense relevant to punishment, an offence is something laid down in a system of law; not necessarily written or codified, but it must be ascertainable by some specified or clearly understood procedure. The Maori parallel to this is a hara (offence), not utu.

These examples demonstrate that a specific legal gloss not only fails to accurately define utu but often conflicts with underlying philosophy of utu.

\section{POTENTIAL SOLUTIONS}

Following our experience of analysing utu, our view is that in order to adequately provide a conceptual understanding of a term such as utu in a specialist legal dictionary, a traditionally formatted dictionary entry, such as that utilised in the Williams dictionary (and to a lesser extent $\mathrm{He}$ Pātaka Kupu) must be adapted to provide additional information about the term in its customary context that will then resource the reader to use the term appropriately.

Two important considerations exist in the case of utu that lead us to the conclusion that a traditional entry crafted out of our list of Western legal glosses would be inadequate.

Firstly, readers should be given clear, albeit brief information to help them gain a customary understanding of utu that can assist them to make sense of the Western legal senses themselves. Such information would add coherence to a range of seemingly unrelated legal senses. As has been seen with utu, its legal senses are sometimes technical and specific, such as "consideration", or as general as "punishment". Inclusion of additional information may assist a user with little experience of the Māori language to understand the link between seemingly unrelated Western legal ideas.

Secondly, while it is by no means controversial or unusual for specialised dictionaries to omit general or original meanings in favour of recording specialised usages, it must be recognised that in the context of the Project it cannot safely be assumed that the original or general meaning of terms such as utu are necessarily well established or understood by the readers. For this reason the dictionary has a particular opportunity to correct incorrect assumptions about the term in a way that may not be achieved simply by presenting the specialised senses of the word. For example, supplementary information about the customary context would be important for conveying the sense that utu was originally more concerned with maintaining relationships than perfectly equal and final exchanges, or the customary importance of the social and political connotations of utu in addition to its economic and transactional ones. In this way, the supplementary information may give readers confidence to use the term in a wider range of contexts in which it would have been customarily applicable.

The Project team decided, in consultation with its steering group, to add a separate paragraphformat field appearing at the head of the formal entry, shaded in a different colour so as to draw the reader's eye to that paragraph. Such information cannot be encyclopaedic, for reasons of cost. For 
the purposes of the final dictionary, which has the primary role of providing users with access to practical legal language, a bare overview which touches on the points above and alludes to further depth and complexity will be sufficient, particularly as the paragraph will be accompanied by references to a recognised text that will provide reliable information on the customary concept. Ideally, this acknowledgement of the customary subtext will pique readers' interest to research further or, at a minimum, encourage them to use the term with care and sensitivity.

The following is a draft entry for the term utu, providing a useful indication of what the final article is likely to look like:



1 cost, price Ki te whakaaro a te nuinga e kore e roa kua eke ki runga rawa te utu mō ngā pata me ngā tīhi o Niu Tīreni ana hokona aua mea i roto i ngā mākete o te ao. @S241896 2 payment, consideration He maha ngā whenua e $£ 2$ e $£ 3$ mō te eka i whakaaria atu e ngā Pākehā noa iho ki ngā Māori hei utu mō aua whenua[.] @S241901.3 pay [E] tino mōhio ana hoki ahau ka tau he mate ki runga i ngā Māori arā ngā kaumātua kāhore nei e āhei te utu i ngā reiti[.] @S241891 4 wages, salary E tino mōhiotia kei te iti rawa te utu mō ētahi o ngā Āteha[.] @S241886 5 expenses, fees I raro i te Ture Kōti Whenua Māori, ko nga moni utu haere e pau ana i te Tiati [...] me ngā moni e pau ana i runga i ngā whakahau rā waho a te Kōti, kāhore e whiua ana ki runga ki ngā whenua o ngā tono e whakawākia ana e te Kōti[.] @ S241896 <cont> utu here bail I roto i ngā whiriwhiri a te Kōti mō ngā tono ki te utu here, ko te tino whakaaro nui a te Kōti ko te painga me te haumaru o te pārurenga[.] @ATL-96a

6 <hist> compensation, recompense Ka taea anō te whakarite tētahi utu mehemea kua pā tētahi tino mate ki ngā tāngata tika ki te whenua. @S241896 7 fine, penalty Ka tika kia whiua te tangata nāna te kurī, te kaitiaki rānei ki te utu kaua e hipa atu i te rima pauna mō ia hara[.] @BIM0504 8 punishment Ko ngā riri oho tata he hē nui tēnā, kia nui anō hoki te utu[.] @BIM0504 This form of utu is used to denote notions of punishment under Western criminal law.

9 answer, response Tērā ahau e utu i taua pātai ana tukua e au ōku kōrero ngā moni o te Koroni[.] @S241891 Often used to refer to an answer given for a parliamentary question.

To a large extent traditional dictionary formatting has been used in this entry. For example, distinct senses have been identified and numbered. One or two word English glosses are included for each sense. An indication as to when the term has been used is provided by a time period marker. Terms that only show <hist> only appear in corpus texts pre 1910. Terms marked with <cont> appear largely after 1970. Terms with no time period marker appear in all time periods of the corpus. On occasion some further information may be provided as to how the term may be used 
in English (preceded by code reference for each such usage example.

This draft entry does not yet include all primary senses identified earlier. However it does suffice to illustrate the overall approach the dictionary team is taking to formulating entries for polysemic customary legal terms. The entry above for example identifies three main categories of utu, visually represented by space between them, into which the primary senses of utu can be grouped. The first group identifies monetary usages, the second group denotes notions of punishment for criminal actions and the third category refers to a neutral notion of exchange or response.

We have not used an innovation such as an atua category as utilised in He Pātaka Kupu. While a Māori worldview would certainly be underscored by the use of such a category it was felt that we lacked the time and expertise to employ such a category for our dictionary, at least for its first edition. It may be that employing such a category would assist users of the dictionary to better understand the customary context in which such terms occur, but the category on its own, in our view, would not necessarily further understanding for many of the users of our dictionary without further explanation and explication of the method than is currently publicly available. We determined that we would mark the importance of the Māori worldview in a different way.

The material in the shaded box at the top of the entry is the new addition to the dictionary entry. This is what we have denoted the whakamaramatanga field, where a very brief explanation is given of the important customary context for the term with a reference to further reading for those readers wanting to find out more about the concept. This is a small amendment, but we consider that its effect will be significant, at least for the dictionary, and perhaps for other specialist dictionaries of indigenous languages where customary concepts remain evocative and ever-present in modern discourse.

\section{IMPLICATIONS AND CONCLUSION}

The work of the Legal Māori Project research assistants over 2010 with the Project as a whole and with the term utu in particular initially uncovered some problems that threatened to undermine the impact and usefulness of the final output of the Project the Legal Māori Dictionary. In a highly polysemic language, as Māori undoubtedly is, the technical legal senses that could be identified in connection with a term such as utu threatened to overwhelm customary understanding of the term, which may have led users of the dictionary to conclude that the customary usages had lost prominence or perhaps even relevance in legal discourse. In short, the process of identifying technical legal glosses for legal Māori language terms began to drive the content of the dictionary in a way that was not altogether desirable for a bilingual dictionary. The research assistants identified that part of the problem of identifying multiple legal senses (initially 26 for utu) was in part driven by their own processes and the unnecessary separation out of very closely related English glosses. 
After readjusting those processes, the list of 26 senses was whittled down to a more manageable list of 11 primary senses.

More importantly though, the researchers also identified that the customary meanings remained critically important to understanding those more technical senses, and it became increasingly obvious that the customary ideas needed to be given prominence within the dictionary format, while still allowing technical Western legal senses to be given due weight.

While the addition of an extra paragraph to the format of certain entries of the forthcoming Legal Māori Dictionary may appear a small gesture in the context of legal dictionary writing, we believe this step, and the work done to identify appropriate senses for inclusion, are important and necessary in order to place customary Māori legal ideas at the centre of the evolution of a dictionary of legal Māori terms. Indeed, the result of our work with the term utu has led us to adopt a similar methodology with other obviously important customary terms that live not only as expressions of Māori law, but of Western law as well. Customary terms and their phrasal variants that occur frequently are being given priority for completion and inclusion in the final dictionary. So far 109 important customary terms have been identified that demonstrate the dual nature of Western and customary legal meaning and that will therefore be treated in the same way as utu. These terms will form a very substantial minority of the terms to be included in the final dictionary and will form its core. These terms are intuitively central to understanding how legal Māori language works and evolves in two changing worlds. 
